\title{
Insects associated with chicken manure in a breeder poultry farm of Central Chile
}

\author{
Insectos asociados a fecas de pollo en una avícola de Chile Central \\ J Retamales ${ }^{\mathrm{a}, ~ *, ~ F ~ V i v a l l o ~}{ }^{\mathrm{a}, \mathrm{b}}$, J Robeson $^{\mathrm{a}}$ \\ anstituto de Biología, Facultad de Ciencias, Pontificia Universidad Católica de Valparaíso, Valparaíso, Chile. \\ bLaboratorio de Biología Comparada de Hymenoptera, Programa de Pós-Graduação em Entomologia, \\ Universidade Federal do Paraná, Curitiba, PR, Brasil.
}

\begin{abstract}
RESUMEN
Los insectos son muy comunes en las instalaciones de la industria avícola y diferentes medidas de bioseguridad se aplican para evitar su propagación debido al hecho que pueden acarrear agentes patógenos. Por lo tanto, es de suma importancia saber qué insectos comúnmente están presentes en los galpones avícolas para optimizar los protocolos de control. Ya que la información sobre este tema es escasa, el objetivo de la presente investigación fue determinar los principales grupos taxonómicos de insectos presentes en el guano de una granja avícola industrial en la zona central de Chile. Las muestras de guano fueron recolectadas en una granja avícola en la Región de Valparaíso, Chile, de áreas adyacentes a las líneas de alimentación y depósitos de agua. Las muestras fueron refrigeradas, transportadas al laboratorio y procesadas para la clasificación taxonómica de los adultos y estados inmaduros de insectos. Los resultados indican una colonización marcada por el escarabajo Alphitobius diaperinus y por los dípteros Fannia sp. en relación con otras seis familias de insectos que se determinaron. Alrededor del $94 \%$ de los insectos encontrados en el guano estaban presentes en las muestras procedentes de las zonas adyacentes a las reservas de agua. Por lo tanto, las fugas de los dispositivos de suministro de agua se han convertido en un punto crítico de control de estas plagas entomológicas de las aves de corral, las cuales han sido reportadas como portadoras de una gran variedad de virus, bacterias y parásitos eucariotas.
\end{abstract}

Key words: Alphitobius diaperinus, insect vectors, poultry farms.

Palabras clave: Alphitobius diaperinus, insectos vectores, galpón avícola.

\section{INTRODUCTION}

The Chilean poultry industry has increased its production with the incorporation of new control technologies to prevent insect colonization (Armijo 2006). However, insects are very invasive and the implemented biosecurity measures do not curtail completely the entry of insects into hatcheries. Therefore, they may become active agents that mediate outbreaks of infectious diseases in birds, generating significant financial losses (Cedó 2001, Ricaurte 2005).

There is evidence that insects have an active role in the transport and spread of various avian pathogens in broiler breeder houses (Gray et al 1999, Olsen and Hammack 2000). Alphitobius diaperinus Panzer (Coleoptera: Tenebrionidae) is a major insect pest on poultry farms worldwide, and besides generating structural damage, pest control expenses and decreased feeding efficiency (Roche et al 2009), it has been associated with the ability to transmit disease agents such as bacteria of the genera Escherichia, Salmonella and Campylobacter (Chernaki-Leffer et al 2002, Segabinazi

\footnotetext{
Accepted: 11.08.2010.

* Av. Universidad 330, Curauma, Valparaíso, Chile; julio_retamales1@ yahoo.es
}

et al 2005, Templeton et al 2006), viruses such as fowl pox and Newcastle (De las Casas et al 1976), fungi of the genera Aspergillus, Penicillium and Candida (De las Casas et al 1972), and protozoans such as Eimeria (Coccidiosis) (Goodwin and Waltman 1996). A. diaperinus also acts as a vector of cecal worms and avian tapeworms (Watson et al 2000).

Despite the importance of insect pest control in the poultry industry, little is known about the entomofauna associated with poultry production and it is scarcely studied in Chile. Therefore, we decided to determine the major insect taxa present in chicken manure in poultry breeder facilities on a major poultry farm in Chile. As a result of this investigation we generated a checklist of the different taxonomic groups of insects associated with poultry faeces in order to facilitate optimization of control measures to minimize dissemination of infectious agents and to preserve or improve the quality of poultry production.

\section{MATERIALS AND METHODS}

\section{SAMPLING}

Insects were collected from eight industrial poultry houses $\left(10 \mathrm{birds} / \mathrm{m}^{2}\right)$ located in the Province of San Antonio, Region 
of Valparaíso, Chile, during April and May of 2005; a total of 432 manure samples of were collected from this site.

Each house was open-sided with the long axis oriented east to west and containing chickens 43-48 weeks of age at the time of collection. The concrete house floors were covered with a $20 \mathrm{~cm}$ layer of accumulated manure that is removed on a yearly basis. Above that, two feeder lines spanned the length of each house, located at $2 \mathrm{~m}$ from both the north and south walls. The sampling sites, Sector 1 (S1) and Sector 2 (S2), were located under the north and south feeder lines, respectively. Furthermore, two water drinking lines spanned the central region; sampling sites of Sector 3 (S3) were located under these drinking lines. The moisture content of faeces was determined through a visual and tactile analysis of manure (Rivera et al 2007). We found that moisture increased significantly in S3 compared to S1 and S2.

Populations of insects established at 48 weeks of flock age were sampled following Strother and Steelman (2001) with modifications; samples $(0.2 \mathrm{~kg}$ each) were collected using a garden shovel from sites at $\mathrm{S} 1, \mathrm{~S} 2$ and $\mathrm{S} 3$ to a maximum depth of $15 \mathrm{~cm}$, zigzagging along the slopes of the barn houses. The 432 samples were individually deposited in labeled transparent plastic bags and brought to the laboratory in a refrigerated cooler to avoid the deterioration of specimens.

\section{IDENTIFICATION OF THE ENTOMOFAUNA}

Insects were taken out from the faeces samples and placed in labeled vials according to their place of collection and preserved in $70 \%$ ethanol. Within 3 days they were processed for identification. The insects were identified at family and/or species level, depending on the abundance percentage (number of individuals per family / total number of insects found of these taxa) and the distribution (presence of insect family / total number of samples examined) thoughout the breeding barns.

The criteria for identifying adults were based on the taxonomical characters cited by Artigas (1994) and Toro et al (2003). Immature stages were identified according to Chu (1949).

\section{RESULTS AND DISCUSSION}

Insects have the ability to colonize poultry manure and therefore key factors for the establishment of a particular entomofauna are the reproductive and developmental characteristics of insects, the food availability present in the poultry houses and the physical and chemical characteristics, humidity in particular (Strother and Steelman 2001). In fact, both larvae and adults of orders Hymenoptera, Diptera, Coleoptera and Lepidoptera were found in the poultry farm studied. The same groups of insects were described by other investigators (Kaufman et al 2000) with the exceptions of Lepidoptera (Incurvariidae and Eriocraniidae) and Hymenoptera (Formicidae) which presumably were not using the poultry farm houses as a site for oviposition and the development of immature stages (figure 1).

Of the 1,131 insects examined, $74.6 \%$ belonged to the order Coleoptera, the most frequently represented families being Histeridae and Tenebrionidae. The most abundant insect found associated with poultry manure on the farm examined was the beetle Alphitobius diaperinus. This is in agreement with results obtained by

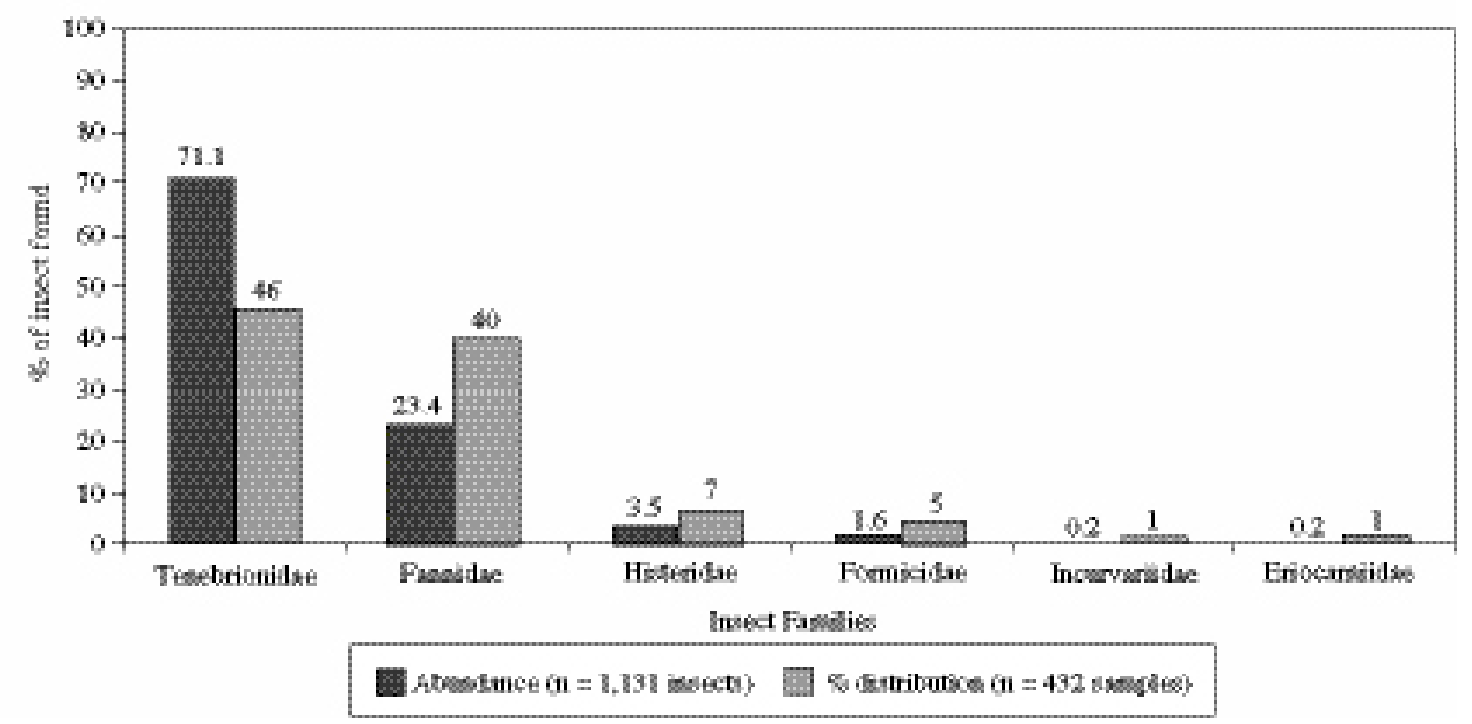

Figure 1. Percentage of abundance (number of individuals per family / total number of insect found) and distribution (presence of family insect / total number of samples examined) of insect families in chicken manure.

Porcentaje de abundancia (número de individuos por familia / número total de insectos encontrados) y distribución (presencia de la familia de insecto / número total de muestras examinadas) de las familias de insectos en el guano avícola. 
Calibeo-Hayes et al (2005) as well as by Strother and Steelman (2001), and Salin et al (2003), who reported that this insect is the most resistant and persistent in avian rearing facilities even when a combination of insecticides is applied.

A. diaperinus is known to be actively involved in the transmission of various infectious agents and parasites found in birds (table I). In natural conditions, results obtained by Chernaki-Leffer et al (2002) and Segabinazi et al (2005) suggest a limited role of A. diaperinus in the spread of Salmonella, a pathogen associated with the poultry industry. Nevertheless, there are still disputes about the role of A. diaperinus in the dispersal of Salmonella in experimental conditions depending on the serovar involved. For example, Davies and Wray (1995) indicate that $A$. diaperinus does not possess the ability to transmit $S$. Enteritidis whereas Roche et al (2009) found that larvae and adults of $A$. diaperinus could act as vectors for the transmission of S. Typhimurium to broilers.
Fannia sp. (Diptera: Fanniidae) was the second most abundant insect found in poultry faeces $(23.4 \%$, only immature stages). It had also been cited as an important colonizer of this kind of faeces worldwide (Kaufman et al 2000). This taxon serves as a mechanical vector of different diarrheal pathogens (Manrique and Delfín 2007). Moreover, Fannia sp. has been recently reported as a vector of Dermatobia hominis larvae (Diptera: Oestridae), an agent that causes myasis in humans and animals (Barreto and Souto 2004).

A. diaperinus and Fannia sp. are present in similar percentages of distribution in the chicken breeding barns examined, followed by Carcinops pumilio (figure 1). Another important feature observed for A. diaperinus and other groups of insects is that the et al onize and establish mainly in areas of high substrate moisture. In fact, $94.1 \%$ of the insects found were associated with the high-humidity manure sector S3. Also, the abundance of A. diaperinus adults and Fannia larvae decreases significantly from sector S3 towards sectors S2 (3.4\%) and S1 (2.5\%).

Table 1. Transport of avian pathogens.

Transporte de patógenos aviares.

\begin{tabular}{|c|c|c|c|}
\hline Insect & & Pathogens & Reference \\
\hline \multirow[t]{19}{*}{ A. diaperinus } & \multirow[t]{3}{*}{ Virus } & Fowl pox and Newcastle virus & De las Casas et al 1976 \\
\hline & & Avian leukosis virus & Eidson et al 1966 \\
\hline & & $\begin{array}{l}\text { Infectious Bursal Disease } \\
\text { (Gumboro Disease). }\end{array}$ & McAllister et al 1995 \\
\hline & \multirow[t]{10}{*}{ Bacteria } & Escherichia coli & Chernaki-Leffer et al 2002 \\
\hline & & Salmonella sp. & Skov et al 2004 \\
\hline & & & Roche et al 2009 \\
\hline & & Campylobacter sp. & Templeton et al 2006 \\
\hline & & & Strother et al 2005 \\
\hline & & & Bates et al 2004 \\
\hline & & Clostridium perfringens & Vittori et al 2007 \\
\hline & & Staphylococcus sp., & Goodwin and Waltman \\
\hline & & Streptococcus sp. & 1996 \\
\hline & & Bacillus subtilis. & De las Casas et al 1972 \\
\hline & \multirow[t]{2}{*}{ Fungi } & Aspergillus, Penicillium & De las Casas et al 1972 \\
\hline & & Fusarium, Candida & \\
\hline & \multirow[t]{2}{*}{ Protozoa } & Eimeria sp. & Goodwin and Waltman \\
\hline & & & 1996 \\
\hline & \multirow[t]{2}{*}{ Helminths } & Cecal worms & Watson et al 2000 \\
\hline & & Choanotaenia infundibulum (tapeworm) & Elowni and Elbiharis 1979 \\
\hline Fannia sp. & Insect & Dermatobia hominis & Barreto and Souto 2004 \\
\hline \multirow[t]{2}{*}{ C. pumilio } & \multirow[t]{2}{*}{ Bacteria } & Salmonella enteritidis & Gray et al 1999 \\
\hline & & Campylobacter sp. & Skov et al 2004 \\
\hline
\end{tabular}

Relation of the main insects found in poultry houses with the transport $\mathrm{f}$ avian pathogens.

Relación de los principales insectos encontrados en las granjas avícolas y el transporte de patógenos aviares. 
The activity of the histerid beetle Carcinops pumilio is interesting to highlight. This insect is known worldwide for its ability to prey upon fly larvae, including the house fly and representatives of the genus Fannia (Tobin et al 1999, Achiano and Giliomee 2006). Therefore, the presence of both tenebrionids and fanniids in sectors of high moisture could be accounted for by the fact that $A$. diaperinus eats the eggs of $C$. pumilio, thus reducing the number of the natural biological controllers of Fannia sp. (Dunford and Kaufman 2006).

Overall, it seems important to investigate the complex interactions between insects in poultry rearing facilities to enhance the use of biological pest control tools in these environments, an approach that could considerably reduce the economic cost incurred by the massive use of insecticides (Kaufman et al 2002).

In summary, the insects reported in this study could generate significant financial losses due to destruction of facilities, parasitism in birds and spread of infectious agents. Nevertheless, some of them play important ecological roles in poultry farms, acting as controlling agents of other insect pest populations, a trait that could be positively employed. Moreover, improvements in water drainage systems become mandatory since they are critical control points for insect pest management.

\section{SUMMARY}

Insects are common in poultry facilities and different biosecurity measures are enforced to prevent their spread due to the fact that they may carry pathogenic agents. Therefore, it is of utmost importance to know what insects are commonly present in poultry sheds to optimize control protocols. Since information on this subject is scarce, this investigation aimed to determine the main insect taxa present in chicken manure on a major poultry farm in Central Chile. Samples of hen manure were collected at a poultry farm in the Region of Valparaíso, Chile, from areas adjacent to feeding lines and water reservoirs. Samples were chilled, transported to the laboratory and processed for taxonomic classification of both adult and immature stages of insects. Results indicated a marked colonization of the beetle Alphitobius diaperinus and of the dipterans Fannia sp.,compared to other six families of insects that were also determined. About $94 \%$ of the insects found in chicken manure were present in samples from areas adjacent to water reservoirs. Therefore, leaks from water supply devices become a critical point of control of these entomological poultry pests that have been reported to carry a variety of viral, bacterial and eukaryotic parasites.

\section{ACKNOWLEDGMENTS}

This work was partially funded by Vicerrectoría de Estudios Avanzados of the Pontificia Universidad Católica de Valparaíso, Chile. Project: DI-UCV 122.705/2008. J Retamales is the recipient of a CONICYT Doctoral Scholarship. We thank Ms. Paola Arenas for revising the manuscript.

\section{REFERENCES}

Achiano K, J Giliomee. 2006. Rearing the house fly predator Carcinops pumilio (Erichson) (Coleoptera: Histeridae) on an artificial diet. Afr J Biotechnol 5, 1161-1166.
Armijo A. 2006. Estudio sobre empresas productoras de pollo. Organización de consumidores y usuarios de Chile, área técnica ODECU, Chile.

Artigas J. 1994. Entomología Económica. Insectos de interés Agrícola, Forestal, Médico y Veterinario. $1^{\mathrm{a}}$ ed. Vol. 2. Ediciones Universidad de Concepción, Concepción, Chile.

Barreto C, S Souto. 2004. Fannia flavicincta (Diptera: Fanniidae): a new vector of Dermatobia hominis (Linnaeus Jr.) (Diptera: Cuterebridae). Rev Bras Zool 21, 115-116.

Bates C, KL Hiett, NJ Stern. 2004. Relationship of Campylobacter isolated from poultry and from darkling beetles in New Zealand. Avian Dis 48, 138-147.

Calibeo-Hayes D, S Denning, M Stringham, D Watson. 2005. Lesser mealworm (Coleoptera: Tenebrionidae) emergence after mechanical incorporation of poultry litter into field soils. J Econ Entomol 98, 229-235.

Cedó R. 2001. Bioseguridad en las granjas. Selecciones avícolas: Jornadas profesionales de producción de carne de pollo, Arenys de Mar, Francia.

Chernaki-Leffer A, S Biesdorf, L Almeida, E Leffer, F Vigne. 2002. Isolamento de enterobactérias em Alphitobius diaperinus e na cama de aviários no oeste do Estado do Paraná, Brasil. Rev Bras Cienc Avic 4, 243-247.

Chu HF. 1949. The Immature Insect. Picture Key Nature Series. University of Illinois, Illinois, USA.

Davies R, C Wray. 1995. Contribution of the lesser mealworm beetle (Alphitobius diaperinus) to carriage of Salmonella enteritidis in poultry. Vet Rec 137, 407-408.

De Las Casas E, PK Harein, DR Deshmukh, BS Pomeroy. 1972. Bacteria and fungi within the lesser mealworm collected from poultry brooder houses. Environ Entomol 1, 27-30.

De Las Casas E, PK Harein, DR Deshmukh, BS Pomeroy. 1976. Relationship between the lesser mealworm, fowl pox and Newcastle disease virus in poultry. J Econ Entomol 69, 775-779.

Dunford J, P Kaufman. 2006. Lesser mealworm, litter beetle, Alphitobius diaperinus (Panzer) (Insecta: Coleoptera: Tenebrionidae). Entomology and Nematology Department, Florida Cooperative Extension Service, Institute of Food and Agricultural Sciences, University of Florida, USA.

Eidson CS, SC Schmittle, RB Goode, JB Lal. 1966. Induction of leukosis tumors with the beetle Alphitobius diaperinus. Am J Vet Res 27, 1053-1057.

Elowni EE, S Elbiharis. 1979. Natural and experimental infection of the beetle Alphitobius diaperinus with Choanotaenia infundibulum and other chicken tapeworms. Vet Res Commun 3, 171-173.

Goodwin MA, WD Waltman. 1996. Transmission of Eimeria, viruses, and bacteria to chicks: darkling beetles (Alphitobius diaperinus) as vectors of pathogens. J Appl Poult Res 5, 51-55.

Gray J, C Maddox, P Tobin, J Gummo, C Pitts. 1999. Reservoir competence of Carcinops pumilio for Salmonella enteritidis (Eubacteriales: Enterobacteriaceae). J Med Entomol 36, 888-891.

Kaufman P, D Rutz, C Pitts. 2000. Pest management recommendations for poultry. Cornell and Penn State Cooperative Extension publication, USA.

Kaufman P, M Burgess, D Rutz, C Glenister. 2002. Population dynamics of manure inhabiting arthropods under an integrated pest management (IPM) Program in New York poultry facilities - 3 case studies. J Appl Poult Res 11, 90-103.

Manrique-Saide P, H Delfín-González. 1997. Importancia de las moscas como vectores potenciales de enfermedades diarreicas en humanos. Rev Biomed 8, 163-170.

McAllister JC, CD Steelman, LA Newberry, JK Skeeles. 1995. Isolation of infectious bursal disease virus from the lesser mealworm, Alphitobius diaperinus (Panzer). Poultry Sci 74, 45-49.

Olsen A, T Hammack. 2000. Isolation of Salmonella spp. from the housefly, Musca domestica L., and the dump fly, Hydrotaea aenescens (Wiedemann) (Diptera: Muscidae), at caged-layer houses. J Food Prot 63, 958-960.

Ricaurte S. 2005. Bioseguridad en granjas avícolas. Redvet 6, 1-17. 
Rivera LE, MR Goyal, M Crespo. 2007. Métodos de medir humedad del suelo. En: Goyal, MR (ed). Manejo de riego por goteo. $2^{\mathrm{a}} \mathrm{ed}$. Recinto Universitario de Mayagüez, Puerto Rico, Pp 27-63.

Roche AJ, NA Cox, LJ Richardson, RJ Buhr, JA Cason, BD Fairchild, NC Hinkle. 2009. Transmission of Salmonella to broilers by contaminated larval and adult lesser mealworm, Alphitobius diaperinus (Coleoptera: Tenebrionidae). Poult Sci 88, 44-48.

Salin C, YR Delettre, P Vernon. 2003. Controlling the mealworm Alphitobius diaperinus (Coleoptera: Tenebrionidae) in broiler and turkey houses: field trials with a combined insecticide treatment: insect growth regulator and pyrethroid. $J$ Econ Entomol 96, 126-130.

Segabinazi S, M Lovato, A Da Silva, G Jacobsen, R Dariva. 2005. Bactérias da família Enterobacteriaceae em Alphitobius diaperinus oriundos de granjas avícolas dos Estados do Rio Grande do sul e Santa Catarina, Brasil. Acta Sci Vet 33, 51-55.

Skov M, A Spencer, B Hald, L Petersen, B Nauerby, B Carstensen, M Madsen. 2004. The role of litter beetles as potential reservoir for Salmonella enterica and thermophilic Campylobacter spp. between broiler flocks. Avian Dis 48, 9-18.

Strother K, D Steelman. 2001. Spatial analysis of Alphitobius diaperinus (Coleoptera: Tenebrionidae) in broiler production facilities. Environ Entomol 30, 556-561.
Strother K, D Steelman, E Gbur. 2005. Reservoir competence of lesser mealworm (Coleoptera: Tenebrionidae) for Campylobacter jejuni (Campylobacterales: Campylobacteraceae). J Med Entomol 42, 42-47.

Templeton J, A De Jong, P Blackall, J Miflin. 2006. Survival of Campylobacter spp. in darkling beetles (Alphitobius diaperinus) and their larvae in Australia. Appl Environ Microbiol 72, 7909-7911.

Tobin P, S Fleischer, C Pitts. 1999. Spatio-temporal dynamics of resident and immigrating populations of Carcinops pumilio (Coleoptera: Histeridae) in high-rise poultry facilities. J Med Entomol 36, 568-577.

Toro H, E Chiappa, C Tobar. 2003. Biología de Insectos. Ediciones Universitarias, Pontificia Universidad Católica de Valparaíso, Valparaíso, Chile.

Vittori J, R Schocken-Iturrino, KC Prochnon, C Martins, G Gomes, L Melo De Souza, C Peters. 2007. Alphitobius diaperinus como veiculador de Clostridium perfringens em granjas avícolas do interior paulista - Brasil. Cienc Rural 37, 894-896.

Watson DW, JS Guy, SM Stringham. 2000. Limited transmission of turkey coronavirus in young turkeys by adult Alphitobius diaperinus (Coleoptera: Tenebrionidae). J Med Entomol 37, 480-483. 